\title{
INVESTIGATION OF PROPERTIES OF MODIFIED BASALT FIBERS
}

\author{
Volodymyr Gots \\ Department of technology of building constructions, wares and materials \\ Kyiv National University of Construction and Architecture \\ 31 Povitroflotskyi ave., Kyiv, Ukraine, 03037 \\ Petr Palchyk \\ Department of technology of building constructions, wares and materials \\ Kyiv National University of Construction and Architecture \\ 31 Povitroflotskyi ave., Kyiv, Ukraine, 03037 \\ PPPalchik@ukr.net \\ Oksana Berdnyk \\ Department of technology of building constructions, wares and materials \\ Kyiv National University of Construction and Architecture \\ 31 Povitroflotskyi ave., Kyiv, Ukraine, 03037 \\ kseniareznik87@gmail.com
}

\begin{abstract}
Thermophysical, physical-mechanical and acoustic characteristics of a rough continuous basalt fiber under the influence of operating factors and a corrosive environment are studied. It is shown that the production of protective materials with high thermophysical and acoustic properties is possible when creating a porous system with a known texture characteristic of pores of different classes, purposes and connections. An influence of the porous system of rough continuous basalt fiber on the operational properties of flexible heat and sound insulation products and materials is studied.

The requirements of normative documents on thermal protection of buildings and structures have caused a constant tendency from the creation of new materials that ensure reliable operation of structures and equipment in the conditions of intensive influence of destructive factors of external influence.

This led to an increase in requirements for walling wall materials that are used to fill openings in frame construction, or as an independent structural and thermal insulation material when building buildings with load-bearing walls. They are presented with a set of requirements that combines: physical and mechanical, chemical, hygienic, thermophysical, decorative and finishing, and other properties of the material. In this connection, there is a need to create materials that, having a small average density and high strength, are able to withstand the temperature loads, and the influence of an aggressive environment.

It is determined that the performance characteristics of flexible heat and sound insulation materials are directly proportional to the degree of porosity of the composite materials and their structural characteristics. It is shown that the increase in the operating temperature of these materials, sound and thermal resistance is determined by the chemical and mineralogical composition of the initial materials and their structural characteristics. The influence of the mechanism of selective leaching of coarse continuous basalt fibers on their texture characteristics and the operating temperature zone is studied.

The resulting material is produced from environmentally friendly raw materials using a one-stage technology without harmful effects on the environment and, unlike thermal insulation materials based on polymers or asbestos, has no harmful effect on the human body, meets the requirements of the European Union for the protection of the environment and sanitary and hygienic standards.
\end{abstract}

Keywords: basalt fiber, porous system, texture characteristics, operating temperature, thermophysical characteristics, acoustic characteristics.

\section{Introduction}

The requirements of normative documents on thermal protection of buildings and structures have caused a constant tendency from creation of new materials that ensure the permanent operation of structures and equipment in the conditions of intensive influence of 
destructive factors of external influence. Such materials are presented with a set of requirements (sometimes mutually exclusive) that should combine: physical, mechanical, chemical, hygienic, thermophysical, decorative and finishing, and other properties of materials. In this connection, there is a need to create materials that, at low average density, high strengths, can withstand significant temperature loads, the influence of extreme natural and operational factors $[1,2]$.

The development of modern technology necessitates the creation of materials that are characterized by a low average density, capable of withstanding the influence of high temperatures and the influence of an aggressive environment. One of such materials is mineral fibers based on igneous rocks. The raw materials for their production are non-deficient, widespread in Ukraine basic rocks of magmatic origin - basalts and their structural analogues: diabase, amphiboles, etc. The relatively low melting temperature makes it possible to use these rocks for the production of mineral fibers according to a simplified scheme, directly with rock loading in the melting unit, which ensures high profitability of the obtained products, stability of process parameters and absence of harmful load In this case, the melting of the starting materials takes place according to the one-stage principle - without the stages of silicate formation and illumination. The aim of the studies is obtaining porous coarse continuous basalt fibers with increased operating temperature.

\section{Materials and methods of research}

Magmatic rocks - basalts and their structural analogs: diorites, gabbros, andesites, syenites of Ukrainian deposits were used for research. The chemical composition of basalts and their structural analogs of some deposits in Ukraine is given in Table 1. Physical and mechanical properties of basalts and their structural analogs are given in Table 2. Basic properties of basalt raw material that determine its suitability for producing mineral fibers of different functions with specified structures, chemical and physico-mechanical characteristics: melting point, melt viscosity at a defined temperature, adjust the cooling rate, the surface tension of the melt and some other properties [3,4], which determine the possibility of control of the technological process. Determination of the basic properties of basalt raw materials and its melt, namely: melting point, melt viscosity, cooling rate, surface tension value, as well as crystallization values and wetting were determined by recognized methods. The melt viscosity was determined by the Margulis and Volorovich methods upper crystallization limit - by hardening, surface tension - by retracting into the melt of a hollow cylinder, the cooling rate basalt melt - by the Aslanov method (1), wetting the surface of solid materials - by "frozen droplet". Determination of the melt value of igneous rock samples were carried out at research basalts and their structural analogues of the fields that are on the territory of Ukraine and conducted geological and engineering-development works. The results of the content of oxides and their melts are given in Table 1-4.

Table 1

Chemical composition of basalts and their structural analogues in some deposits of Ukraine

\begin{tabular}{ccccccccc}
\hline & & \multicolumn{5}{c}{ Chemical composition, $\%$} \\
\cline { 3 - 8 } No. & Fiber & $\mathbf{S i O}_{2}$ & $\mathbf{T i O}_{2}$ & $\mathbf{F e}_{2} \mathbf{O}_{3}$ & $\mathbf{A l}_{2} \mathbf{O}_{3}$ & $\mathbf{C a O}$ & $\mathbf{M g O O}$ & $\mathbf{R}_{2} \mathbf{O}$ \\
\hline 1 & Usachkovsky deposit & 48,7 & 0,8 & 13,5 & 15,9 & 12,9 & 5,4 & 3,5 \\
2 & Talne deposit & 47,6 & 1,5 & 16,6 & 17,5 & 9,5 & 5,1 & 4,6 \\
3 & Romny deposit & 49,0 & 0,6 & 11,7 & 17,5 & 10,4 & 5,3 & 4,7 \\
4 & Yanova Dolina deposit & 50,6 & 0,9 & 14,8 & 16,0 & 9,8 & 5,1 & 3,2
\end{tabular}


Table 2

Physical and mechanical properties of basalts and their structural analogues of some deposits of Ukraine

\begin{tabular}{ccccc}
\hline Rocks & Density, $\mathbf{~ k g} / \mathbf{m}^{\mathbf{3}}$ & Poisson's ratio & Compressive strength, MPa & Young's modulus, Pa \\
\hline Syenite & $2600-2750$ & 0,23 & $150-300$ & 6,7 \\
Gabbro & $2900-3100$ & 0,2 & $100-250$ & 7,1 \\
Basalt & $2520-2970$ & $0,20-0,25$ & $60-400$ & $6,2-11,3$ \\
Andesite & $2280-2680$ & 0,22 & $80-240$ & 10,8 \\
Diorite & $2725-2920$ & 0,3 & $155-280$ & 7,4
\end{tabular}

Table 3

Chemical and mineralogical composition of some basaltic deposits

\begin{tabular}{ccccccccccc}
\hline No. & Deposit & $\mathbf{S i O}_{2}$ & $\mathbf{T i O}_{2}$ & $\mathbf{A l}_{2} \mathbf{O}_{3}$ & $\mathbf{F e}_{2} \mathbf{O}_{3}$ & $\mathbf{F e O}$ & $\mathbf{M g O}$ & $\mathbf{C a O}$ & $\mathbf{N a}_{2} \mathbf{O}$ & $\mathbf{K}_{2} \mathbf{O}$ \\
\hline 1 & Kryvyi Rig & 54,6 & 0,2 & 13,3 & 1,9 & 9,0 & 5,5 & 4,44 & 2,09 & 1,31 \\
2 & Berestovetske & 49,03 & 2,85 & 12,59 & 3,88 & 9,8 & 5,4 & 9,54 & 2,34 & 0,66 \\
3 & Selchevske & 55,6 & 0,66 & 19,4 & 7,54 & 7,5 & 3,8 & 7,91 & 1,86 & 1,56 \\
4 & Yanova Dolina & 48,8 & 2,75 & 15,0 & 8,47 & 6,3 & 5,1 & 8,34 & 1,5 & 0,75
\end{tabular}

Table 4

Properties of melts of basalt rocks and their structural analogs of some deposits of Ukraine

\begin{tabular}{|c|c|c|c|c|c|c|c|c|}
\hline \multirow{2}{*}{ No. } & \multirow{2}{*}{ Rocks } & \multirow{2}{*}{ Deposit } & \multicolumn{4}{|c|}{ Viscosity, $\mathbf{n s e c} / \mathrm{m}^{2}$ at temperature, ${ }^{\circ} \mathrm{C}$} & \multicolumn{2}{|c|}{ Surface tension, ${ }^{\circ} \mathrm{C}$} \\
\hline & & & 1540 & 1420 & 1350 & 1200 & 1400 & 1540 \\
\hline \multirow{2}{*}{1} & \multirow{2}{*}{ Basalt } & Janova Dolina, Rivne region & 7,4 & 11,7 & 18,0 & 34,8 & 354 & 352 \\
\hline & & Haina-Chokhrak Donetsk region & 5,1 & 5,7 & 18,0 & 34,8 & 354 & 352 \\
\hline \multirow{2}{*}{2} & \multirow{2}{*}{ Diabase } & Isachkovske, Poltava region & 6,7 & 7,4 & 10,6 & 21,3 & 352 & 349 \\
\hline & & Romny & 8,7 & 10,2 & 12,4 & 20,6 & 361 & 346 \\
\hline 3 & Amphibolyte & Talne, Cherkasy region & 9,1 & 12,5 & 18,7 & 81,0 & 364 & 298 \\
\hline
\end{tabular}

Note: The significance of some indicators of melts of basaltic rocks and their structural analogues are used on the basis of research (2)

\section{Research results of the basalt fiber viscosity}

As can be seen from the results of the experiments given in Table 1-4, the lowest value of the viscosity value has a solution of basaltic charge from basalts with an increased content of iron compounds (in ferrous and oxide form), manganese compounds and alkali metals. These materials include basalts of the Haina-Chokhrak deposit in the Donetsk region; and vice versa - the basins of the Yanova Dolina of the Rivne region, which contain an increased content of aluminum, titanium and calcium compounds, show the highest values of melt viscosity parameters. Correspondingly, the melting points of the basalt burden of these deposits are in inverse relationship $\left(1390{ }^{\circ} \mathrm{C}\right.$ for the Haina-Chokhrak deposit in the Donetsk region and for the Yanova Dolina, Rivne region). The temperatures of the upper and lower boundaries of the crystallization of basalt melts of different deposits are in the range of $1165 \ldots 1295{ }^{\circ} \mathrm{C}$, and also depend on their chemical composition and structural characteristics of the rock [6-9].

Experiments on determining the rate of cooling of basaltic melt of different deposits in Fig. 1 show that melts with an increased content of iron and alkali metal compounds (curves 2 and 3 ) have a considerably lower cooling rate in comparison with solutions (curve 1) in which the content of iron and alkali metal compounds is limited in the range of $8 \ldots 11 \%$ and $0.8 \ldots 1.4 \%$ [10-12]. The experimental-industrial batch of rough continuous modified basalt fibers was 
obtained on the technological line of JSC "Belichi factory "Thermal insulation" (Ukraine, Kotsiubynske).

Subsequent processing of the fiber bases in order to obtain design characteristics is completely performed on laboratory equipment of the Kyiv National University of Construction and Architecture. The parameters and operating modes of the equipment of the production line, the composition and the ratio of the components of the raw materials, the temperature and the time of the values of the modification of the basalt fiber are established in accordance with the calculated values that ensure the obtaining of the operational characteristics of the heat-sound-insulating products.

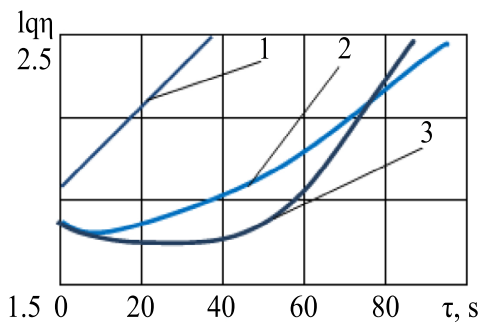

Fig. 1. Rate of cooling of the melt of basalt rocks and their structural analogues:

1 - Melt with low content of iron and alkali metal compounds; 2 - Melt with increased content of iron compounds; 3 - Melt with increased contents of compounds of iron and alkali metals

These features of the cooling rate of basalt melt of different deposits can be explained by a decrease in the temperature transparency of melts with an increased content of iron and alkali metal compounds. Thus, the most important properties of basaltic melts, which enable the formation of a continuous coarse fiber with the achievement of specified characteristics, is the viscosity of the melt and its crystallization properties.

The results of determining the stability of basalt fibers in solutions of different chemical nature are given in Table $\mathbf{5}$.

Table 5

Stability of uninterrupted coarse basalt fibers in solutions of different chemical nature *

\begin{tabular}{|c|c|c|c|c|c|c|c|c|c|}
\hline \multirow{3}{*}{ No. } & \multirow{3}{*}{ Deposit } & \multicolumn{8}{|c|}{ Corrosive solutions } \\
\hline & & \multicolumn{2}{|c|}{$\mathrm{H}_{2} \mathrm{O}$} & \multicolumn{2}{|c|}{$1,0 \mathrm{n}, \mathrm{NaOH}$} & \multicolumn{2}{|c|}{$2.0 \mathrm{n}, \mathrm{NaOH}$} & \multicolumn{2}{|c|}{$2.0 \mathrm{n}, \mathrm{HCI}$} \\
\hline & & Mass mg & Stability \% & Mass mg & Stability \% & Mass mg & Stability \% & Mass mg & Stability \% \\
\hline 1 & Janova Dolina & 12,5 & 96,53 & 16,1 & 95,56 & 151,0 & 48,0 & 221,1 & 39,1 \\
\hline 2 & Isachkovske & 22,15 & 96,1 & 152,4 & 73,0 & 230,2 & 59,1 & 364,8 & 35,0 \\
\hline 3 & Talne & 11,6 & 99,7 & 38,4 & 98,9 & 349,0 & 90,7 & 188,0 & 49,9 \\
\hline 4 & Haina-Chokhrak & 40,9 & 98,5 & 129,3 & 95,5 & 496,0 & 82,7 & Solute on & Solute on \\
\hline
\end{tabular}

Note: * The significance of some indices of chemical resistance of continuous rough basalt fiber was used on the basis of studies (2)

As can be seen from the results of the experiments given in Table 5, the water and alkalinity of basalt fiber is quite high. The acid resistance of the fibers under study is much lower, but also at the level of acid resistance of fibers made of aluminoborosilicate glass [13, 14].

\section{Discussion of the results of the production of porous siliceous fibers}

Thus, as a research results, basalt fibers can be conditionally divided into such groups.

1. Insoluble with the preservation of the shape and color of the fiber.

2. Partially soluble in acids to form a bulk porous structure.

3. Completely soluble. 
Of these, the most interesting, from the point of view of the goal, is the basalts of the Usachkovske and Romny deposits.

The determination of physico-mechanical and thermophysical parameters of the second group of basalt fibers (at this stage) was carried out according to the indicators of their texture.

Methods for obtaining porous silica fibers and determining their texture characteristics are given in $(6,7)$. Texture characteristics mean: volume of sorption pores $(\mathrm{V})$, total pore volume $\left(\mathrm{V}_{0}\right)$, specific surface of sorption pores $(\mathrm{S})$; the average radius of sorption and macropores $\left(\mathrm{r}, \mathrm{r}_{\mathrm{m}}\right)$. In these works, the influence of the chemical composition of the feedstock, as well as the conditions of acid and heat treatment of the fibers on the texture of the fibers obtained from them, was also determined. These studies have shown that the texture of silica fibers depends on the conditions of their processing, and it is possible to regulate it by one or more of the above factors within rather wide limits.

Analyzing the research results, it is necessary to note certain regularity in properties of initial materials and in conditions of carrying out of experiments. In the vast majority of cases basalt fibers were used for the experiments, which were obtained immediately after blowing up the basalt melt. Thus, the fiber material acquired certain structural features, which are due to the nature of their production, and are inherent in virtually all types of basalt fiber. This is due to the high cooling rate of the basalt melt during blowing. The so-called "thermal memory" is superimposed on the material of basalt fiber, and, accordingly, on its properties, which largely determines their basic properties. Thus, when studying the leaching process, the structural features of the basaltic material were not taken into account, and the influence of the structure of the material on the corrosion resistance of the fiber was virtually excluded from the leaching process.

At the same time, it is known $[3,4]$ that under the influence of certain technological factors, as well as environmental parameters, the basalt material can have several structural varieties, namely, vitreous, porcelain-like, recrystallized, initial, and some other modifications. It is taken into account that the different structure of basalt material should serve as the reason for different properties of basalt fiber, including different chemical resistance. Research is conducted to determine the technology and methods for the production of porous basaltic fiber of large diameters with high thermal engineering and physico-mechanical characteristics. It is determined that the texture characteristics of basalt fibers can be regulated by technological factors, the effectiveness of influence and the direction of their action is determined by certain dependencies.

Thus, the basis for researching the ability of vitreous basalts, which have an increased amount (49\%) and, accordingly, a smaller amount of calcium and magnesium oxides, do not dissolve in hydrochloric acid, but leach out. This circumstance indicates that the resistance of a fiber from basalt rocks depends significantly on the chemical composition of the starting material. Since basalt fibers are characterized by high resistance to the influence of water and alkaline solutions, their chemical resistance to the influence of acidic solutions becomes one of the important criteria in choosing the composition of basalt rock, which is recommended for fiber production.

Thus, as a result of research, certain ways and methods of obtaining flexible heat and sound insulation products based on modified basalt fibers with increased operating temperature.

These products can be used for thermal and acoustic insulation of thermal machines, units, and heat networks in the conditions of the influence of an aggressive environment.

The study on selective leaching of basalt fibers is a continuation of previous work to determine the ways and methods for obtaining heat and sound insulation materials with an increased operating temperature, environmentally friendly, with minimal impact on the environment.

\section{Conclusions}

According to the obtained results, a porous basalt fiber with the texture of given parameters can be obtained by using basalts of certain deposits. This provides a porous quartzoid fiber with high operating temperature $\left(1800^{\circ} \mathrm{C}\right)$, which significantly exceeds the operating temperature of basalt fibers $\left(940^{\circ} \mathrm{C}\right)$. 


\section{References}

[1] Strelkov, K. K., Mamykin, P. S. (1978). Tekhnologiya ogneuporov. Moscow: Metallurgiya, 375.

[2] Kutepov, A. M., Bondareva, T. I., Berengarten, M. G. (1990). Obshchaya himicheskaya tekhnologiya. Moscow: Vysshaya shkola, 520.

[3] Kashcheev, I. D., Strelov, K. K., Mamykin, P. S. (2007). Himicheskaya tekhnologiya ogneuporov. Moscow: Intermet Inzhiniring, 747.

[4] Strelov, K. K. (1985). Teoreticheskie osnovy tekhnologii ogneupornyh materialov. Moscow: Metallurgiya, 480.

[5] Dyudkin, D. A., Uhin, V. E. (2004). Ogneupory i ih ehkspluataciya. Available at: http://uas.su/ books/refrectory/refrectory.php

[6] Kaynarskiy, I. S., Degtyareva, E. V. (1974). Osnovnye ogneupory: syr'e, tekhnologiya i svoystva. Moscow: Metallurgiya, 367.

[7] Konkin, A. A. (Ed.) (1978). Termo-, zharostoykie i negoryuchie volokna. Moscow: Khimiya, 424 .

[8] Konkin, A. A. (1974). Uglerodnye volokna i drugie zharostoykie voloknistye materialy. Moscow: Khimiya, 376.

[9] Medvedev, A. A., Tsybulya, Yu. L., Bendik, N. I., Kuziv, P. (2000). Kompozitsionnye materialy na osnove bazal'tovykh i khimicheskikh volokon. Sostoyanie i perspektivy. Khimvolokna-2000. Tver: OAO «Tver'khimvolokno», Rossiyskaya Inzhenernaya akademiya, 535-539.

[10] Dzhigiris, D. D., Makhova, M. F., Sergeev, V. P. (1989). Bazal'tovoloknistye materialy. Promyshlennost' stroitel'nykh materialov. Ser. 6: Promyshlennost' polimernykh, myagkikh krovel'nykh i teploizolyatsionnykh stroitel'nykh materialov. Moscow: VNIIESM, 3, 72.

[11] Hots, V. I., Palchyk, P. P., Berdnyk, O. Iu. (2018). Enerdgy-efficiency in civil engineering and architecture. Naukovo-tekhnichnyi zbirnyk. Kyiv, 10.

[12] Hots, V. I., Palchyk, P. P., Rieznik, O. Iu. (2012). Vplyv temperaturnoi obrobky bazaltovoho volokna na yoho teksturni kharakterystyky. Budivelni materialy ta vyroby, 45, 18-21

[13] Hots, V. I., Palchyk, P. P., Rieznik, O. Yu. (2011). Armuvannia bazaltotsementnoho viazhuchoho. Resursoekonomni materialy, konstruktsii, budivli ta sporudy. Rivne: NUVHP.

[14] Hots, V. I., Palchyk, P. P., Zhubinska, M. V., Rieznik, O. Iu. (2010). Doslidzhennia zalezhnosti khimichnoi stiikosti bazaltovoho volokna vid osoblyvostei tekhnolohii vyrobnytstva, khimichnoho skaldu syrovyny ta kontsentratsii rozchynu, shcho travyt. Resursoekonomni materialy, konstruktsii, budivli ta sporudy. Rivne: NUVHP. 